\title{
1. Corporate law and the legal environment of the firm
}

\section{INTRODUCTION}

'Society is produced by our wants, and government is produced by our wickedness; the former promotes our happiness positively by uniting our affections, the latter negatively by restraining our vices. The first is a patron, the last a punisher', Thomas Paine (1995: 5, emphasis in original) writes in his influential pamphlet Common Sense, published in 1775-76. In his Two Treatises of Government (first published in 1690), another foundational work for the liberal, modern society, John Locke emphasized that law making is ultimately based on 'the public good':

Political power, then, I take to be a right of making laws with penalties of death, and consequently all less penalties, for the regulating and preserving of property, and of employing the force of the community, in the execution of such laws, and in the defence of the commonwealth from foreign inquiry; and all this only for the public good. (Locke, [1690] 2003: 10; Book II, §3)

In these liberal treatises, man is a creature capable of both creation and destruction, and therefore society needs to be built on constitutional rights and legislation that effectively combine liberating and controlling features, yet obey the principle of common good. Following Mannheim's (1986) argument, Paine's position is exemplary of a liberal view, locating law at the centre of the constitutional rights that are capable of protecting the individual from the sovereign or other actors granted legislative powers. In contrast, Mannheim (1986: 56) says, conservatism is based on what he calls mythical transcendence, the reliance on notions such as 'the nation', 'the monarchy', 'the people', or - in our case - 'the market' as being what can serve as a warrant for individuals' rights and well-being. 'Liberal theory is based on the mentality of the Eighteenth-century Enlightenment, while conservative theory rests primarily on romanticism', Mannheim (1986: 55) suggests. While conservatives are prone to justifying beliefs and practices on the basis of abstract (mythical, in Mannheim's parlance) terms, 'liberal-bourgeois thought' sets the problem 
of liberty and well-being 'predominantly upon a juristic plane, specifically in conjunction with natural law', Mannheim (1986: 56) argues: '[t]he legitimacy of a form of rule is justified by means of purely ideological constructions, which generate the meanings required, always at the juristic level of validity (social contract)' (emphasis in original). One of the earliest accounts of such a legalistic view of constitutional rights is Spinoza's ambition to separate religious doctrines from the wider social contract, today widely recognized as a key constitutional feature (the right of 'religious freedom') but being nothing short of heresy even in the liberal and culturally sophisticated seventeenth-century Amsterdam. Says Spinoza (2009: 195): '[i]f men were naturally bound by the Divine law and right, or if the Divine law and right were a natural necessity, there would have been no need for God to make a covenant with mankind, and to bind them thereto with an oath and agreement'. While this distinction between the mythical transcendence of conservatism and the legalistic orientation of 'liberal-bourgeois thought' may appear as an archetypal procedure of academic hair-splitting, it is in fact of relevance for the forthcoming discussion, as corporate governance is widely understood as what is embedded in either the rule of law or the rule of the market, or, in most cases, a combination thereof.

As the economy, the totality of economic value creation and distribution activities, is a central element of any advanced and differentiated society, Thomas Paine's (1995) proposition regarding government is applicable also in economic organization, by definition outside of political and regulatory bodies. Institutional economic theory in particular emphasizes the role of legal, regulatory and law-enforcing agencies that monitor and thus shape economic life. Douglass North (1991: 97) defines institutions as 'the humanly devised constraints that structure political, economic, and social interaction. They consist of both informal constraints (sanctions, taboos, customs, traditions, and codes of conduct), and formal rules (constitutions, laws, property rights)'. In North's neoclassical view of institutions, their primary role is to 'reduce transactions and production costs per exchange' so that trade can be realizable. That is, institutions' role is to secure operative economic relations (for example, markets) that better exploit differences in production factor costs and the benefits of division of labour. In North's (1991: 98) view, institutions include both political and economic institutions. Ultimately, the value and raison d'être of these institutions is derived from their ability to lubricate the economy and to promote the production of economic value and growth. More specifically, North (1991: 105) lists three types of institutional innovations: (1) 'those that increased the mobility of capital', (2) 'those that lowered information costs', and (3) 
'those that spread risks'. In practical terms, such institutional innovations include, for example, forms of market creation, the establishment of regulatory control that prevents and punishes opportunistic behaviour, and activities that increase the supply of financed capital.

Neoclassical economic theory is generally speaking uneasy when it comes to the role of regulatory agencies. As unregulated markets are ex hypothesi the most efficient way to process information, to discount risks, and to price commodities and services, any regulatory initiative is suspiciously treated as an unnecessary complication and the presence of polity within strict economic undertakings. As a consequence, much research on institution-building is located in disciplines such as economic history, political science and economic sociology, more receptive to the idea of the need for monitoring markets and assuming that markets are not naturally occurring phenomena but human accomplishments. In other words, much research is directed towards understanding how policymaking (as a form of institution-building in North's use of the term) is structured in accordance with certain norms and beliefs. Campbell (2002) here introduces the term cognitive parading in policy-making work, being defined as '[t]aken-for-granted descriptions and theoretical analyses that specify cause and effect relationships, that reside in the background of policy debates and that limit the range of alternatives policy makers are likely to perceive as useful' (Campbell, 2002: 22). In addition, Campbell (2002: 27) speaks more narrowly about frames in policymaking, being '[n]ormative and sometimes cognitive ideas that are located in the foreground of policy debates'. In a similar vocabulary, Schmidt (2008: 306) emphasizes the role of cognitive ideas in policymaking, being certain dominant ideas that "provide the recipes, guidelines and map for political action and serve to justify policies and programs by speaking to their interest-based logic and necessity'. In addition to the cognitive ideas, Schmidt (2008: 307) suggests that normative ideas also shape the policy-making work: '[n]ormative ideas instead attach values to political action and serve to legitimate the policies in a program through references to their appropriateness'. Such concepts underline how policy-making is an ongoing process of creating meaningful scenarios for how policies can influence and shape, for example, economic activities in ways that are desirable for the policymakers and their constituencies (for example, voters). Campbell (2002: 30) portrays the policy-makers as epistemic communities being 'networks of professionals and experts with an authoritative claim to policy-relevant knowledge, who share a set of normative beliefs, causal models, notions of empirical validity, and a common policy enterprise'. While such an epistemic community is likely, like any other professional community 
(for example, scientists, professional musicians), to become a selfregulating social world unto itself, policy-making is exposed to detailed media attention that, at least in theory, makes them responsive to public opinions and wider social interest. 'In order for their policy programs to be adopted, political elites strategically craft frames and use them to legitimize their policies to the public and each other', Campbell (2002: 27) writes.

Studies of policy-making and policy-enforcing organizations such as the IMF, the World Trade Organization (WTO), the World Bank and central banks reveal that the work in these organizations is a complex, politicized and in many ways slow process to align heterogeneous interest and objectives (Fernández-Albertos, 2015; Chwieroth, 2010; Conti, 2010; Chorev and Babb, 2009; Griffin, 2009; Neu et al., 2006). In many cases policy-making unfolds on the basis of predominant frames and cognitive and normative ideas, political as well as economic, but they are fundamentally moulded by emergent political interests of member organizations (for example, nation states). This makes policy-making on the international level a time-consuming and in many ways tedious process that provides a test of the tenacity of the participants. In some cases, the political inertia of such organizations is treated as evidence of an innate inefficiency of these organizations, but the slowness of the advancement of regulatory frameworks should probably not be interpreted as an indication of regulatory value.

One specific form of institution in competitive capitalism is the corporate charter, the incorporation of businesses (originally) within the realm of the state as a principal vehicle for economic activities. Corporate law is one of the most central juridical-political innovations in the institutional framework of competitive capitalism and yet, as will be demonstrated in this volume, economic theory in many ways ignores or diminishes the influence of corporate law as being one of the fundamental innovations in the capitalist economy. Once instituted, many legal-juridical innovations become infrastructural, that is, they are ignored 'as long as they work', and there is thus the risk of making a category mistake (using Gilbert Ryle's apt term) when assuming that free market capitalism is a naturally occurring economic condition while in fact it is buttressed by a variety of legal framework and regulatory procedures. This fallacy of treating efficient markets not so much as human accomplishments but as some original, primordial natural state will be subject to critical analysis in this volume. 


\section{DEVELOPING BUSINESS CHARTERS AND CORPORATE LAW}

The rise of the 'corporate organizational form', Kaufman (2008: 402) argues, has long been regarded as 'one of the defining innovations of the modern era'. The 'corporate system' (Eisenberg, 1989: 1523) in turn relies on the enactment of corporate legislation and the possibility to incorporate businesses, a legal innovation that was one of the major institutional innovations of the eighteenth and nineteenth centuries. These business charters instituted by corporate law and granted by the legislators offered a number of benefits for the promoters: '[c]orporate assets are legally protected from both shareholders and creditors in many cases, thus creating a legal shield between corporate actors and corporate responsibilities. In the contemporary context, corporate assets are also subject to different taxation and regulation schemes than unincorporated businesses' (Kaufman, 2008: 403).

If nothing else, the sheer growth in numbers of business charters in the American states that passed corporate laws testifies to their usefulness for entrepreneurs and promoters. By the year 1800, 'only 335 charters had been issued in the United States for business corporations'; by 1890 , there were 'nearly 500,000 business corporations' (Blair, 2003: 389, footnote 3). In addition to empirical evidence, Kaufman (2008: 405) suggests that the history of incorporation and corporate law is ' $[\mathrm{k}]$ ey to understanding the relationship between the state and the public and private spheres'. That is, corporate law (and other relevant legislation) serves to define and establish boundaries between the rights of the state and the rights of the individual in quite specific ways.

The history of corporate law thus needs to be examined in detail to render latter-day debates regarding trust versus market control in the corporate governance literature meaningful. Siding with a number of prominent legal theorists and economic historians, Kaufman (2008) argues that corporate law has medieval roots and that the very concept of the corporation is a relatively recent complement to a wider socioeconomic governance problem of how to legitimize and monitor business ventures. In fact, in the early period of incorporation, most of the business charters were not given to corporations but to a diverse set of organizations:

The legal structure of the modern corporate form derives from efforts in medieval Europe to grant legal autonomy to universities, towns, and ecclesiastical institutions. Trade guilds and commercial monopolies were also 
granted corporate status in special circumstances. Even the earliest corporations thus represent the delegation of state authority to subsidiary entities, a form of power-sharing that raised questions about the extent and limit of the powers of both the incorporator and the incorporated. (Kaufman, 2008: 403)

In post-revolutionary America, the new republic now hosted a number of organizations (including the President and Fellows of Harvard College, the oldest business charter on the continent, dated to 1650, 14 years after its inception) that had been granted business charters under English law. After 1776, the individual states strategically employed business charters to constitute themselves as autonomous, sovereign legislators separated from the federal state. But again, just as in the case of Europe, "[t]he majority of private corporations chartered between 1780 and 1810 were not business concerns at all; they were churches, townships, schools, and voluntary organizations' (Kaufman, 2008: 404). In fact, of the incorporations registered in Massachusetts (the leading state in terms of the nominal number of incorporations and with the oldest corporate legislation - Rhode Island had more incorporations per capita measured in terms of 'white males') during the period 1791-1800, only 4 per cent were 'non-infrastructure businesses' (while 24 per cent of all business charters were granted to 'infrastructure companies'). Handlin and Handlin (1945) stress that corporations were originally regarded as a government agency, serving the public interest:

At its origin in Massachusetts the corporation was conceived as an agency of government, endowed with public attributes, exclusive privileges, and political power, and designed to serve a social function for the state. Turnpikes, not trade, banks, not land speculation, were its province because the community, not the enterprising capitalists, marked out its sphere of activity. (Handlin and Handlin, 1945: 22)

In addition to the relatively minor role of companies in the legislative practices and law making, the 'institutional success' of corporate law was not, Lamoreaux (2009: 17) argues, immediately secured as the federal parliament and thereafter the state courts were prone to use business legislation as a political resource: '[a]fter the American Revolution, responsibility for chartering corporations had devolved on the various state legislatures. These bodies initially assumed that they had powers akin to those of Parliament to alter or revoke charters, and they did not hesitate to meddle in corporate affairs'. A decisive change came about in 1819, finally separating business charters from the state legislatures, when the US Supreme Court ruled in favour of the Dartmouth College trustees who had filed a lawsuit challenging an act of the New Hampshire 
legislature. Writing for the Court, Chief Justice John Marshall declared that state legislatures '[d]id not inherit Parliament's boundless powers over corporations but, rather, had to acknowledge the superior authority of the Constitution' (Lamoreaux, 2009: 18). From now on, business charters were protected by the federal constitution, widely interpreted as a Supreme Court decision favouring market-based control of incorporated business ventures:

Over time, state and federal courts not only upheld the notion of freedom of incorporation but also began to defend the sanctity of the private corporation from state interference ... Arguably, judges expanded their conception of the public good to embrace America's increasingly brisk economy. Private gain was heralded as a key component of the public good, a rationalization that would subsequently come to undergird all American political-economic policy. (Kaufman, 2008: 419)

Taken together, Kaufman (2008) argues, it would be inadequate to think of corporate law as what was initially developed to maximize efficiency and transparency in business ventures. Instead, Kaufman (2008: 406) argues, '[n]ew legal doctrines form without conscious design but are instead post hoc responses to social and legal conditions that change and cumulate over time'. The common law, within which corporate legislation was originally enacted, rendered the corporation as '[a] relatively undifferentiated organizational form' that could be used for a variety of purposes (Kaufman, 2008: 420). It is therefore historically inconsistent to project today's corporate system and legislation onto the legal statutes of the earliest corporate laws. Corporate law is frequently the outcome of reactive responses to emerging problems leading to court ruling; the responsiveness and agility of the legal system is thus a better explanatory factor when it comes to understanding the statutes of corporate law than to adhere to a rationalist credo assuming that corporate law is formulated under the favourable conditions of certainty and the capacity to anticipate latter-day governance problems. 'Courts and legislatures have not always been consistent in their vision of the American private corporation, but the long-term trend has been toward greater corporate autonomy, except in cases where the openness of markets is at stake', Kaufman (2008: 421) summarizes.

\section{THE ROLE OF CORPORATE LAW}

In many cases, there is a confusion regarding the corporate law and economic theories of the firm more broadly in the literature. While 
economists tend to think of the firm as a vehicle for economic value creation and economic value extraction within the domain of the market economy, legal scholars generally take a wider and more socially embedded view of the firm. Legal scholars treat the firm as a legal entity being incorporated within the social organization to benefit wider social and political objectives rather than merely providing a more narrow range of benefits including, for example, shareholder value creation. Bratton (1989a: 1471), a legal scholar, stresses that for economists, the firm 'is a legal fiction that serves as a nexus of contractual relationships among individual factors of production'. This view, where the firm is understood as a black box that transforms input production factors to output goods and services, is addressed by Bratton (1989a: 1472) as the "contractual view of the firm'. As will be discussed in more detail in Chapters 2 to 4 in this volume, contractual theory of the firm represents one quite specific legal tradition that is not always of necessity compatible with the claims made by, for example, agency theorists. In contrast to the contractual view, legal theory assumes that the firm is more than a bundle of contracts; instead, the corporation is granted rights from the state and should therefore be seen in a wider socio-political and economic context than the contract view implies (Bratton, 1989a: 1475). Kaufman and Zacharias (1992) argue that the difference between the contractual view of the corporation and the semi-professional view of management based on fiduciary duties in corporate law represents a deep-seated concern regarding autonomy and accountability in American society: 'American and legal theorists have looked at the market, liberty's principal arena, for an important supplement to democratic rule. By delineating the private from the public sphere, the market allegedly created a social space in which individuals could determine their life stories from public or government influence' (Kaufman and Zacharias, 1992: 524).

Even after World War II, in the era of managerial capitalism and where the efficiency of large firms and management's technical competence were evident to most commentators, these anxieties regarding the privileges and discretion of managerial elites persisted. The legitimation crisis of the professionally managed corporation was cushioned by corporate law, capable of 'reconciling management's dictatorial control with the nation's constitutional ideals' (Kaufman and Zacharias, 1992: 528), and corporate law provided a vocabulary for articulating management as a profession. More specifically, this vocabulary '[c]ame largely from fiduciary doctrines that held the responsibilities of trustees to be morally more arduous than conventional market relationships' (Kaufman and Zacharias, 1992: 528). That is, corporate law endowed professional 
managers with fiduciary duties and discretion that by and large protected them from market-based evaluations.

Eisenberg (1989) stresses that, in practice, the corporation is governed on the basis of a combination of legal rules and rules derived from market conditions:

A corporation is a profit-seeking enterprise of persons and assets organized by rules. Most of these rules are determined by the unilateral action of corporate organs or officials. Some of these rules are determined by market forces. Some are determined by contract or other forms of agreement. Some are determined by law. (Eisenberg, 1989: 1461)

Eisenberg (1989) here distinguishes three basic categories of rules: (1) enabling rules, which 'give legal effect to rules that corporate actors adopt in a specific manner'; (2) suppletory or default rules, which 'govern defined issues unless corporate actors adopt other rules in specific manner'; and (3) mandatory rules, which 'govern defined issues in a manner that cannot be varied by corporate actors' (Eisenberg, 1989: 1461). In addition, in the practical day-to-day work in corporations, Eisenberg (1989) argues, it is useful to distinguish between (1) structural rules, which 'govern the allocation of decisionmaking power among various corporate organs and agents'; (2) distribution rules, which 'govern the distribution of assets (including earnings) to shareholders'; and (3) fiduciary rules, which 'govern the duties of managers and controlling shareholders' (Eisenberg, 1989: 1462). When speaking about corporate law, it is thus important to keep in mind that some rules are mandatory, not open to negotiations, while other governance rules rely on the managers' and directors' ability to adopt rules that best fit the intentions of the legislators to promote business venturing. Taken together, corporate law is a non-trivial domain of jurisdictional expertise that cannot easily be understood on the basis of, for example, economic theory frameworks or, more generally, preferences regarding alleged efficient governance principles.

Eisenberg (1989) notes that corporate law can be applied somewhat differently in the three cases of (1) closely held corporations, having few shareholders frequently being directly involved in the management of the firm; (2) publicly held corporations, for example, listed companies with widely dispersed ownership; and (3) firms that are to be introduced to the stock market through IPOs (Initial Public Offerings) (Eisenberg, 1989: 1463). Despite these differences, the corporate law system is in all three cases based on the same principles of the corporate system that have been 
established over time in the American society and the legal system, Eisenberg argues (1989):

The American economy is a corporate system, in the sense that control of the economic factors of production and distribution is vested largely in the hands of privately appointed corporate managers. This system is legitimated on three major bases. The first is the belief that the shareholders, as the owners of the corporations, have the ultimate right to control it. The second is the belief that corporate managers are accountable for their performance. The third is the belief that placing control of the factors of production and distribution in the hands of privately appointed corporate managers, who are accountable for their performance and who act in the interest and subject to the ultimate control of those who own the corporation, achieves a more efficient utilization of economic resources than that achievable under alternative economic systems. (Eisenberg, 1989: 1523)

Blair (2003) argues that business historians have identified three plausible explanations for the popularity of the corporate form: (1) it amassed 'large amount of capital'; (2) it provided 'limited liability' for the investors (representing one decisive legal innovation in the modern period, Handlin and Handlin, 1945: 11, notice, as there was "no clear precedent from Roman law' and 'early English law knew nothing of limited liability') $)^{1}$; and (3) it centralized the control of the corporation (Blair, 2003: 389). Blair (2003: 390) adds a fourth factor as being a 'critical advantage of the corporate form': '[t]he ability to commit capital, once amassed, for extended periods of time - for decades or even centuries'. Blair explains that not only did the owners of a new business charter need to protect the corporation from the investors' creditors to enable long-term stability to promote economic growth, the corporate form justified the establishment of a "pool of assets that was not subject to being liquidated or dissolved by any of the individual participants who might want to recover their investment' (Blair, 2003: 392). In other words, the corporate form not only protected investors ('participants' in the business charter, in Blair's parlance) from the individual investors' creditors, potentially harming the interest of less indebted investors, but it also provided a mechanism that protected the investors from their own proclivity to use the corporation as a form of deposit: '[t]he commitment of capital by shareholders ... helped protect the at-risk investments made by other corporate participants', Blair (2003: 392) writes. This mechanism is of great importance for the analysis of the institutionalization of the corporate form as a legal entity as it strongly undermines the claim that, for example, shareholders have the right to command resources amassed within the corporation. By the legal strictures of corporate law, 
directors (and, de jure, the managers hired by the directors) are given an autonomous position to manage the 'pool of assets' controlled by the corporation; the basic legal principle underlying US corporate governance, stated in $\$ 141$ (a) of Delaware General Corporation Law, is that '[t]he business and affairs of every corporation ... shall be managed by or under the direction of a board of directors' (cited in Moore and Rebérioux, 2011: 96). Says Blair (2003):

Incorporating a firm created a governance mechanism which separated the role of contributing financial capital from the role of operating the business and making regular decisions about the use of assets in the business. When the corporation is formed, initial investors not only commit a pool of capital to be used in the business, but they also yield control over the business assets and activities to a board of directors that is legally independent of both shareholders and managers. (Blair, 2003: 393)

In other words, the success of corporate law derived not only from its ability to legitimize the social role and status of professional managers, but also less abstractly, because it enables incorporated business charters to operate efficiently as corporate prescribed shared rules, procedures and obligations for all partners and stakeholders:

The corporate form ... provided a more reliable basis for building organizational capital than did either an individual proprietorship or partnership. To build sustainable organizations, individuals with sufficient talent and expertise to run a business operation had to be induced to give up their own entrepreneurial aspirations in order to work in a business in which they would not be independent and might now share directly the potential business profits. The corporate form gave stability to the business enterprise, which helped ensure those professional managers that their firm-specific investments would be protected, along with the dedicated physical and financial capital, and that they would have substantial input in how the business would be run. (Blair, 2003: 427).

Corporate law was therefore a principal vehicle for taming opportunistic behaviour and for aligning various stakeholders' - most notably the business partners' - own interests within one single legal entity.

\section{The Growth and Differentiation of the Corporation}

In the latter half of the nineteenth century, American railroad companies were incorporated and they developed large hierarchies and dispersed ownership, leading to the need to formulate corporate laws that enabled this modern type of organization to operate as smoothly as possible 
(Bratton, 1989a: 1486). As Hilt (2014) makes clear, the corporate law was not so much establishing the firm as a set of contracts between business partners and their owners (holders of stock) or creditors, as it was a contract between the state and the business partners; the firm is from the very beginning incorporated within the socio-economic realm of the state. In the period after 1880, the railroad company model of the managerial firm was widely spread in the growing American economy (Perrow, 2002), leading to the development of a new class of professional management workers and executives:

Hierarchies of salaried executives dominated these new corporations. Successful mass production required long-term policy commitment and substantial investment; professional, salaried managers were designated to make these formulations and to direct production. Actors on the capital markets withdrew from active participation in corporate management because they saw themselves as lacking necessary expertise. (Bratton, 1989a: 1487)

In this period, the modern corporate firm was instituted, relying on a combination of hierarchical organization, salaried professional managers and dispersed ownership. Quite early on it was evident that influential capital owners and venturesome executives found ways to create oligarchies and monopolies, and such tendencies were counteracted by political activism leading to new legal frameworks. The Sherman Antitrust Act of 1890 'outlawed restraints of trade by existing monopolies and any attempt to create a new monopoly' (Cassidy, 2009: 128), and the Clayton Antitrust Act of 1914 'proscribed price discrimination, exclusive dealing contracts, and other predatory tactics that the trusts had used to boost their profits' (Cassidy, 2009: 128). By and large, there was substantial political support for the state regulating and monitoring industry through corporate law, antitrust legislation, regulations and law enforcement in the period.

During the depression following the great Wall Street crash of 1929 and in the New Deal era, it was widely debated whether this combination of legislation, regulation and law enforcement was enough to curb the oligarchic tendencies in competitive capitalism, and many scholars, policy-makers and politicians spent a significant amount of time pondering how to balance different interests in the economy (Hawley, 1966). The Glass-Steagall Act of 1933 and the Securities Act of 1934 that created the Securities and Exchange Commission (SEC), the agency monitoring the finance industry, were two New Deal products aimed at strengthening the control of the state over private enterprises (Hilt, 2014: 8.16). The period from the mid-nineteenth century to the decade before the outbreak of World War II was thus a period wherein corporate law 
was instituted as a means for the state to balance private enterprising and public interests. As Hilt (2014: 8.17) remarks, the legal environment of the privately owned or public firm was the outcome from the legal, political and regulatory engineering of a system that aimed to balance various interests and objectives: 'the solutions to [corporate governance problems] have sometimes been sought in legal innovations, and in other cases, institutional or market-based solutions emerged'. Speaking in legal terms, the American corporate law system could be seen, Hilt (2014: 8.18) argues, as a "partially codified hybrid of common-law institutions and indigenous innovations'. Eisenberg (1989: 1525) shares this view, that corporate law is best understood as an assemblage of various types of legal rules, market-based rules and managerial decisions jointly combined to accomplish the highest possible efficiency, transparency and stability in the corporate system:

[b]elieving that just because markets are not perfect, mandatory rules would be better ... However, the converse proposition is also true: just because mandatory rules are imperfect does not mean that markets would be better ... The brute facts are that most markets are not perfect and most mandatory rules are perfect; that even imperfect markets and legal rules may have positive effects; and that the question in any given case is to determine which of these two imperfect mechanisms is better, or, if possible, to determine how these two imperfect mechanisms can be shaped to reinforce each other. Taken separately, neither markets, morals, nor law, are in themselves sufficient to curb traditional and propositional conflicts. Taken together, markets, morals, and law have shown themselves capable of achieving that objective. (Eisenberg, 1989: 1525)

In other words, legislative practice, an attention to market conditions, and moral standards are all important elements in the development of the corporate system that is a key mechanism in competitive capitalism and that supports enterprising activities at the same time as stability and transparency is enabled. As with many other successful institutional innovations, gradually becoming 'infrastructural' inasmuch as they are no longer even recognized as once being quite innovative or even radical mechanisms and practices as they become taken for granted and even deemed to be of minor interests, the innovation of corporate law suffers from this ignorance, Blair (2003: 393) suggests:

The corporate form does not now seem so unique and remarkable, so that its benefits might seem trivial. But it is worth exploring what it was that made the corporate form so attractive to business organizers as the US economy moved from an agrarian, small-scale production economy to a large and modern industrial economy. (Blair, 2003: 393) 
The corporate system instituted and contributed to the building of competitive capitalism, and yet - as we will see in the following chapters of this volume - it was from the 1970s widely regarded by agency theorists as in fact inhibiting the efficient use of resources.

\section{CORPORATE LAW AND REGULATIONS}

One important distinction in corporate governance is between law and regulations. Wherein the former specifies legal entities and their relations as a juridical condition that remains relatively stable over time, regulation is a political tool to accomplish certain objectives and goals within existing legal frameworks. Posner (1974: 335) argues that regulation refers to 'taxes and subsidies of all sorts as well as to explicit legislative and administrative controls over rates, entry, and other facets of economic activity'. Among free market protagonists such as Posner (1974), regulations are by and large undesirable as policy-makers intervene in supposedly self-regulating markets and thus bias the competition, which in turn reduces the overall market efficiency. George Stigler (1971: 3) suggests that, 'as a rule', regulation is '[a]cquired by the industry and is designed and operated primarily for its benefit'. Regulation is thus here the outcome from industry putting pressure on policy-makers and regulators to establish non-market-based subsidies and other benefits being in their own interests. Trade barriers and import quotas are typical examples of such regulations that can protect domestic producers from external competition. Stigler (1971: 16) argues that regulation therefore is beneficial for some but not all actors in an economy, and therefore regulations are undesirable as they grant certain groups benefits that others are denied: '[w]hen an industry receives a grant of power from the state, the benefit to the industry will fall short of the damage to the rest of the community'.

Despite such criticism from free market advocates, regulation is widely popular in political quarters, primarily because politicians and policymakers are engaged with a wider set of social and economic interests than to ensure optimal market efficiency, and regulations provide them with political tools that help them fulfil their political agendas and promises. The regulation studies literature points at many different effects, benefits and unintended consequences of regulation and deregulation, making regulatory factors a key issue to consider for corporations. One body of literature emphasizes how corporate interests and lobbying strongly influence regulatory procedures, which therefore risks influencing the political process to regulate markets and industries (Hiatt and 
Park, 2013; Abraham and Sheppard, 1999). In some cases, such as the levels of executive compensation, there may be a political will to establish a regulatory framework, and yet there are difficulties involved in regulating industry (Suárez, 2014). One of the factors to consider is the lobbying industry and the flow of finance capital between industry and the policy-making community in, for example, Washington DC and Brussels.

Thornburg and Roberts (2008) study the enactment of the SarbanesOxley Act, the foremost consequence of the Enron bankruptcy and the evidence of corporate crime in the American energy company, and they find that the accounting industry contributed heavily both to political candidates ( $\$ 15354056$ to 'federal candidates during the 2000 election cycle') and lobbyists (\$21 777 432) (Thornburg and Roberts, 2008: 233) and that the primary recipients of these donations were incumbent legislators who were members on committees 'having jurisdiction over SOX' (Thornburg and Roberts, 2008: 245). This flow of finance capital suggests, Thornburg and Roberts (2008: 245) conclude, that '[p]olitical strategies focus more on interests of business and its members than on the interests of the broader public'. Mian et al. (2010) observe a similar pattern in the case of the American Housing Rescue and Foreclosure Prevention Act (AHRFPA) and the Emergency Economic Stabilization Act (EESA) that followed the declining sub-prime mortgage market (for details, see Mian and Sufi, 2014; Dymski, 2013; MacKenzie, 2012; Levitin and Wachter, 2012; Engel and McCoy, 2007. For a more personal account of the consequences of the unregulated home mortgage industry, see Andrews, 2009). The Wall Street Journal described AHRFPA as '[t]he most important piece of housing legislation to come along in a generation' (Mian et al., 2010: 1971), as there were large economic interests being affected by the new legislation. Mian et al. (2010: 1969) found that 'a strong predictor of voting behavior on EESA is the amount of campaign contributions from the financial service industry'. Mian et al. (2010: 1969) say this finding is 'consistent with anecdotal evidence suggesting that the financial industry lobbied heavily to shape the EESA and get it passed'. The causality between campaign contributions and voting behaviour is thus linear in Mian et al.'s (2010: 1969) empirical material, at least for 'politicians running for reelection', but not for 'retiring politicians'. Mian et al. (2010) also identified a correlation between a conservative ideology and voting behaviour, where Republicans were more sceptical regarding the regulatory control of the state intervening in market activities. The finance industry - the 'mortgage industry', in Mian et al.'s (2010) vocabulary - was also quite precise in how they allocated their donations, targeting politicians from districts 
with a 'high fraction of subprime borrowers' (Mian et al., 2010: 1997). Both Thornburg and Roberts (2008) and Mian et al. (2010) show how the regulatory political process is easily becoming a case of 'vending machine politics' (Froud et al., 2004: 905) as campaign donations and other forms of economic support can easily and legitimately find their way to policy-makers in democratically elected political bodies. Under all conditions, in periods of economic and financial instability, the regulatory process becomes pervaded by specific interest and the money such interests bring with them, making an already complicated process even more difficult to handle (Humphrey et al., 2009).

\section{Regulation and Innovation}

In addition to the imbrication of financial interest and the regulatory process, there is a body of literature that emphasizes how innovation activities may benefit from regulatory standards (Faulkner, 2009; Ashford et al., 1985), but that also shows how innovations can undermine regulation. Faulkner (2009) argues that the field of tissue engineering benefits from clearer regulatory frameworks, and that the European Union should actively engage in regulating the emerging field of research and venturing to help the actors coordinate themselves within the grids of regulatory practices and standards. On the other hand, Phillips et al. (2011) argue that too much regulation can make it complicated for actors to get the leeway they need to innovate effectively. In the finance industry, subject to waves of regulation and deregulation over the last decades (for example, Lépinay, 2011; Abdelal, 2007; Singer, 2007; Hammond and Knott, 1988), and where a substantial body of literature regards regulatory failure in combination with excessive risk-taking as the two main factors explaining the finance industry meltdown in 2008 (Jarsulic, 2013; Silvers, 2013; Friedman and Kraus, 2012; Campbell, 2010), innovations have played a key role in making the old regime of regulatory control obsolete or at least less efficient. A scholarly research question worthy of some attention is thus how and why the regulation failed.

Martinez-Moyano et al. (2014) observe what they refer to, following Vaughan (1999), as the 'normalization of deviance' in the finance industry. Including a sample of 70 regulators, Martinez-Moyano et al. (2014) found evidence of 'flexible rule following' operating within its very own political economy of risk and benefits, granting organizations the possibility to follow regulatory rules when it suited their interests: 'organizations attend to rules depending on the salience, time horizon, and relative certainty of the benefits of production compared with those 
of compliance' (Martinez-Moyano et al., 2014: 332). One of the factors contributing to the normalization of deviance from rules, MartinezMoyano et al. (2014) argue, is the short-term perspective taken by organizations where the short-term benefits of flexible rule-following tend to win over medium to long-term risks of being punished for not respecting the regulatory framework.

In some areas, including financial markets, rule enforcement erodes when the short-term benefits of production diminish concerns about unspecified, distant risks from rules or procedural violations ... Beliefs, cognitive assumptions, formal and informal procedures, and rewards for completing transactions versus maintaining tight internal controls reinforce the bias towards completing transactions and away from equally mindful enforcement of rules. (Martinez-Moyano et al., 2014: 333)

Clark and Newell (2013) use the term complicit decoupling to denote a policy drift that occurs when organizations that collaborate and rely on each other (for example, rating agencies and firms issuing bonds) gradually lower the standards for professional integrity and change the role as providers of objective and neutral information. The long-term consequences of such complicit decoupling between the formal relations of two or more parties and their actual collaborations lead to a gradual decline in the efficiency of regulatory frameworks, and therefore also harm the efficiency of market transactions. In other words, regulation is always of necessity socially embedded inasmuch as it presupposes that certain values and norms, not of necessity made explicit in the regulatory statutes, are internalized by relevant actors (Bozanic et al., 2012).

Such policy drifts and complicit decoupling do not only occur when self-serving actors choose to act opportunistically to benefit their own interests, but they are also caused by innovations. In the field of life science innovation, Niezen et al. (2013) demonstrate how the structuring of databases has informed the regulation of the pharmaceutical industry. Lenglet (2011) shows how the use of algorithmic trading and the work of 'quants' - skilled mathematicians employed in the finance industry have shaped finance industry regulation. In the finance industry, Frame and White (2004) suggest, financial innovations can be grouped into (1) new products (for example, 'adjustable-rate mortgages, exchange-traded index-funds'); (2) new services (for example, 'online securities trading, Internet banking'); (3) new 'production' processes (for example, 'electronic record-keeping for securities, credit scoring'); and (4) new organizational forms (for example, 'a new type of electronic exchange for trading securities, Internet-only banks') (Frame and White, 2004: 118). Frame and White (2004: 121) also say that 'some forms of regulation 
must inhibit innovation', but also recognize that 'innovation can arise from efforts to circumvent regulation'. At the end of the day, it is 'impossible a priori to assign a positive or negative sign to the connection between the stringency of regulation (however measured) and the pace of financial innovation' (Frame and White, 2004: 121). Under all conditions, Frame and White (2004: 118) argue that financial innovations that lead to the improvement of the finance industry will have 'direct positive ramifications throughout the economy'.

Funk and Hirschman (2014: 670) argue that financial innovations serve to undermine existing regulatory frameworks inasmuch as new financial interests such as swaps resist the categories of existing regulatory frameworks and therefore gradually render regulations ineffective in monitoring financial transactions and the level of risk-taking. Funk and Hirschman (2014: 671) define regulation as '[1]imitations on the products a firm can offer, the price at which it may offer those products, or the location where it may do business'. Over time, the deregulation of the markets, beginning in the late 1970s and early 1980s, was first propelled by consumer interests, serving, for example, to increase the supply of credit in the US finance market. From the late 1980s and onwards, industry interests substituted consumer interest (Funk and Hirschman, 2014: 671). In the finance industry, the standard explanation for the substantial deregulatory efforts is, in Suárez and Kolodny's (2011: 77) formulation, that the ' $[\mathrm{r}]$ egulatory environment of the late 1990 s can only be understood through the political behavior of individual firms and of the membership organizations that represented them in Washington'. The deregulation of the finance industry is thus the outcome of the activism of pro-business communities and lobbyists, and political mobilization is the primary driver for the changes in regulatory oversight. Funk and Hirschman (2014: 673) add that regulation and business activities (including innovation) maintain a 'dialectical relationship': ‘just as businesses respond to regulation by complying with regulation (or not) and innovating (or not), regulators and legislators respond to changes in the behaviors of business by enforcing existing regulations (or not) or creating new ones (or not)' (Funk and Hirschman, 2014: 673).

Examining the case of the repeal of the Glass-Steagall Act of 1933, Funk and Hirschman (2014: 677) proposed that the finance industry first try to alter established regulatory frameworks through 'traditional lobbying efforts', but as the efforts were only moderately successful, they had the incentive to develop innovations that were ambiguous and 'ill-defined with respect to contemporary regulatory categories'. As, for example, swaps became widely used in the finance industry, accompanied by new more lenient principles for how existing regulatory rules should be 
interpreted, more or less derived from a more generous pro-business and pro-finance industry attitude of the late 1990s, the balance of power between regulators and finance industry actors changed, paving the way for the overturning of the Glass-Steagall Act (Funk and Hirschman, 2014: 692). In other words, while the finance industry deregulation of the late 1990s, with the repeal of the New Deal regulation of the GlassSteagall Act, certainly benefited from political activism and lobbying and the pro-business climate, the practical work to create new financial assets became the coup de grâce for the extant regulatory framework as these innovations escaped the existing interpretative framework and thus undermined its efficacy and legitimacy.

The question is then how well 'laws in books' and 'laws in real life' are aligned - whether the map accurately depicts the territory - or if there is room for local interpretations and enactment of corporate law. There are reasons to believe, based on studies of policy-making processes in organizations such as the IMF and the World Bank, that there is a loose coupling between policy-making in practice and scholarly ideas about, for example, market efficiency. Babb (2013) discusses how what she calls policy paradigms (that is, free market efficiency theories) may be partially influenced by 'scholarly ideas', but ultimately the outcome is shaped by the political processes developed within the organizations that negotiate various policy programmes: 'although policy paradigms are both inspired and legitimated by scholarly theories, they are also shaped by politics' (Babb, 2013: 271). That is, policy-making and regulations are not collected from scholarly treatises and journal articles and implemented en bloc but are shaped and moulded by the procedures for political policy-making. Despite the inertia and bargaining of policymaking, policies do after all become enacted, and they gradually trickle down to the level of everyday work in organizations: policies become part of the legal environment of the firm.

\section{LAW IN BOOKS AND LAWS IN REAL LIFE}

Institutional theorists and legal scholars argue that laws are enacted by the legislator to be followed but also to accomplish other benefits, for example, to signal what society tolerates and regards as appropriate and desirable behaviour. In addition, legislation is shaped by the possibilities of enforcing the law in practice, making certain legislation most cumbersome to handle from a practical perspective. Halliday and Carruthers (2007: 1142, 1146) make an important distinction between 'law making' - 'law in the books' - and 'law implementation' - 'law in practice': 'Law 
in practice refers to behavior and institutions that constitute and enact law as it actually is experienced by those it regulates' (Halliday and Carruthers, 2007: 1146). While law in the books per se may be subject to debates and interpretations and animated discussions regarding their interpretation and applications, law in practice is even more complicated, being operationalized and rolled out as a variety of activities that are more or less loosely coupled with the underlying legal strictures. 'Law on the books and law in action are two quite different things', Halliday and Carruthers (2007: 1196) summarize. Among legal scholars and institutional theorists, there is an ongoing and lively debate regarding the intersection of law and institutions and the various implications thereof. Edelman and Suchman (1997: 493) distinguish between a material (a 'functionalist') and a 'cultural view' on law, suggesting that '[c]ultural perspectives see law as a pervasive belief system that permeates the most fundamental morals and meanings of organizational life'. The functionalist views tend to regard legal texts as an expression of a 'common will' in society or the consent among informed legislators regarding the law in a specific domain of interest. The cultural view, in contrast, recognizes that all legislation is the outcome of bargaining and negotiations wherein various groups express their own interests and concerns regarding the legislation in the making: "legal regulations are often "enacted" $\ldots$ at a fairly local level, with intraorganizational professional constituencies playing a significant part in determining which institutional norms and scripts get reflected in organizational structures and practices', Edelman and Suchman (1997: 499) say. In this view, where laws are regulated, specific professional communities (for example, lobbyists) serve at times to amplify and reify 'legal threats that may have little to do with reality', Edelman and Suchman (1997: 500) suggest. Edelman et al. (2011) introduce the term the legal field to denote the various organizations and professional communities that actively participate, directly or indirectly, in the legal work: '[1]egal fields comprise courts, legislatures, administrative agencies, legal academia, and all legal actors, as well as the various parties that enter into the legal system on an occasional basis' (Edelman et al., 2011: 900).

More specifically, regardless of whether the material or cultural view of legislation work is the most adequate description of the process, legislation recursively both influences the organization and is influenced by the organization's activities. Edelman and Suchman (1997: 507) thus follow Edelman's (1990) seminal paper and use the term legal environment to denote how laws 'create, constrain, shape, enable, and empower organizations'. This is the very core of the institutional view of law, the idea that 'laws in books' are translated into legal environments ('laws in 
practice') that in various ways shape and inform how an organization acts under certain conditions. Seen in this view, there is relatively loose coupling between law, regulatory practices and organizational activities: '[r] egulatory environments place law in the posture of seeking to control organizations, but much regulation grows out of organizations' actions and agendas, and organizational responses to regulations often define the meaning of compliance' (Edelman and Suchman, 1997: 507). In Edelman et al.'s (2001) account, the process when formal legislation is trickling down to practical managerial work is referred to as the managerialization of law, the work of managers to interpret and 'reify' legal texts as practices that preferably suit their own interests.

\section{The Managerialization of Law}

Edelman et al. (2001: 1592) define the managerialization of law as ' $[\mathrm{t}] \mathrm{he}$ process by which conceptions of law may become progressively infused with managerial values as legal ideas move into managerial and organizational arenas'. This is a term that denotes how laws in books are translated into the legal practices seated within the firm, and thus become aligned with the interests of organization actors. This process is also mediated by legal experts and consultants who work on behalf of the companies to interpret the existing legislation to capture and accommodate the intentions of the legislators:

Because law is broad and ambiguous and is rarely read directly by employers, most organizational actors rely at least indirectly on the legal profession for information about legal requirements. Lawyers often run workshops for personnel professionals or write for their professional periodicals, and personnel professionals in turn communicate the law to their employers and others who make organizational policy. As law is communicated by and among professionals, it is filtered through a variety of lenses, and colored by different professional backgrounds, training, and interests. (Edelman et al., 2001: 1595)

Legal texts are often complex documents; on the one hand they seek to bridge and bond all the interests, issues and concerns that the legislators need to take into account, and on the other hand the law needs to be intelligible for lay audiences and so that it can be enforced by the state and international organizations. Legal texts are thus complicated to decode and there may be many interpretations of them. This interpretation and translation of law into practice therefore demands specialized expertise. In addition, not only are the legal documents per se far from trivial to decode, but the very act of decoding the legal text is embedded 
in an environment where, for example, organizational actors interpret a new legal document in their own interests, Edelman et al. (2001: 1598-9) suggest:

Managers tend to understand law - and the legal environment more broadly as a set of constraints upon the range of possible management styles that will achieve organizational goals ... Thus, as legal ideas move into managerial and organizational arenas, law tend to become 'managerialized', or progressively infused with managerial values. (Edelman et al., 2001: 1598-9, emphasis in the original)

The very process of the 'managerialization of law' thus occurs as '[m]anagement consultants rhetorically refashion legal ideas that challenge traditional managerial prerogatives and suggests new ideas, which they claim are more innovative, more rational, and more progressive' (Edelman et al., 2001: 1592). In short, the managerialization of law is to some extent the component of a 'reframing of law' in ways that 'make it appear more consistent with traditional managerial prerogatives' (Edelman et al., 2001: 1592). This may sound as if legal counsellors and consultants can freely choose to interpret the law as they or their clients wish, but much of the legal texts provide possibilities for interpretation and interpreting legal texts in terms that favour existing managerial prerogatives, and discretion is a human response to new legal directives. Using a term first introduced by Philip Selznick (1949), Edelman et al. (2001: 1599) say that the law is 'infused with managerial values'.

There are many consequences of the managerialization of law. First, there is no straightforward implementation of legislation in the corporation, but legal texts are always subject to local interpretations and applications that suit local interests and existing practices; there is "no simple one-to-one causality involved' when laws are implemented, Swedberg (2003: 6) argues. This does not suggest that legislators give managers carte blanche to implement the law as they wish, but there needs to be a reasonable consistency between the intentions of the legislator (a key term in legal theory and legal practice) and actual outcomes. In many cases, as we will see below, the degrees of freedom granted when reading the legal texts lead to corporations being more ambitious than the legislators possibly expected or even wanted, leading to unanticipated consequences of law. Second, while formally speaking the legislator monitors and controls the subject of legislation (that is, the corporation), it would be a mistake to regard this as a linear top-down process because legislation can serve, like any other regulation, as a form of subsidy or benefit in the hands of the corporation. From a sociological perspective, Swedberg (2003: 7) says, law is '[c]losely connected to the 
notion of order, and that order is crucial to society as well as to power elites'. In fact, Swedberg proposes, law can be seen as '[o]ne of the many weapons in the arsenal of power, similar to physical coercion'. The managerialization of law is therefore precisely the process wherein legal texts are appropriated within the firm, partly to regulate and control its activities, and partly to be used to the firm's advantage to further strengthen strategic positions and competitive advantages.

\section{EMPIRICAL STUDIES OF LEGISLATION AND ORGANIZATIONAL AND INDUSTRY RESPONSES}

The institutional theory idea of the managerialization of law has been complemented by a series of empirical studies that reveal how legislation leads to both anticipated and desired outcomes and unintended consequences that extend outside the legislators' immediate interests. This latter consequence, the inability to anticipate the full consequences of legislation, is a standard objection to the state and the government intervening into, for example, market-based activities, allegedly biasing the market and redirecting the attention of market actors. Studies of the implementation of law partially support such claims but proponents of legislation and regulation as legitimate means of the state to control the economy and economic activities point to the benefits derived from, for example, stable market conditions, and stress how legislating and regulatory bodies are the market makers of competitive capitalism.

Many studies of the effects of new legislation deal with labour market regulation and industrial relations including, for example, diversity management legislation (Edelman et al., 2001) or sexual harassment legislation (Dobbin and Kelly, 2007), but there are also studies conducted regarding more policy-oriented legislation, including, for example, antitrust legislation (Kelly and Dobbin, 1999). In many cases, there is a loose coupling between legislation and organizational practices, but as long as the intentions of the legislators are understood and the corporations ensure that they have taken action to act in accordance with such intentions, such loose couplings can be tolerated, as, for example, Dobbin and Kelly (2007) argue. For instance, sexual harassment is widely recognized as an unethical and immoral act where one party violates the integrity of the other party, and therefore legislators want to ensure that corporations share this legal-moral view and that they institute routines for the handling of sexual harassment complaints within the firm. However, Dobbin and Kelly (2007) argue that the legislation does not specify in detail what routines the corporation should implement. Instead, 
it is a general compliance with the legislator's identified social problem that is the principal outcome from the legal text, Dobbin and Kelly (2007) propose:

Executives prefer formal bureaucratic remedies that can routinize legal
compliance, but it is also the case that the courts have come to reinforce such
solutions because they constitute standards that can be applied across cases.
What matters, before the courts, is not whether the employer has a system for
addressing harassment complaints and preventing harassment that has been
proven effective, in the workplace in question or anywhere for that matter, but
whether the employer has a system that symbolizes commitment to those
ideals. (Dobbin and Kelly, 2007: 1237)

In the legislator's view, the managers are in a better position to decide what 'formal bureaucratic remedies' best respond to local demands, and they thus delegate the responsibility for implementing routines to executives and directors. Therefore, the 'symbolic commitment' to the counteracting of undesirable personal intimacies in the workplace is a principal accomplishment of the existing legislation.

In other cases, new legislation can be interpreted as what is favourable to corporate interests, and therefore corporations choose to be more ambitious and even more progressive than the legislators possibly anticipated or even hoped for, simply because the implementation of new policies may strengthen competitive positions. Baron et al. (1986) examine how the new 'personal administration' legislation in the US, relatively vague in terms of prescribing what actions need to be taken, led to the expansion of human resource management departments and human resource management as a field of professional expertise more broadly. This led to a major shift in American industry where the 'tyranny of the foremen' (see, for example, Jacoby, 1985) was substituted by more formal and transparent labour relations in industry. The federal government had defined high turnover in certain industries as the initial problem and favoured legislation to reduce the turnover problem. The federal government was thus mandating a set of innovations that gradually crystallized into what is today's HRM practices (Baron et al., 1986: 364):

The number of personnel and labor relations professionals in the United States increased from fewer than 3,000 in 1946 to 53,000 in 1950 and 93,000 in $1969 \ldots$ in percentage terms, the growth rate of the personnel profession far outstripped the growth rate of other professions (and of the U.S. labor force as a whole) during the postwar years. (Baron et al., 1986: 375)

In this case, one specific problem and its accompanying legislation, not very precise in its prescribed corporate practices, led to a series of new 
organizational innovations. HRM thus became established as a response to the problem of high turnover, and was spread through the force of what institutional theorists refer to as mimetic isomorphism (DiMaggio and Powell, 1983). These 'unintended consequences of legislation', Kelly and Dobbin (1999: 485) suggest, are a consequence of what they refer to as 'legal ambiguity', an incomplete and to some extent vague legal intention, a form of blank surface onto which legal counsellors and executives can jointly project their perceived solutions to new legislation. This legal ambiguity can therefore, Kelly and Dobbin (1999: 485) say, 'lead to strong corporate responses'. For instance, Kelly and Dobbin (1999: 485) suggest that many American employers implemented maternity leave programmes in the 1970s and 1980s, well before the passage of the Family and Medical Leave Act of 1993, simply because they either saw this legislation coming and wanted to discount the additional cost that the reform and new legislation would induce, or because they saw such benefits as being to their advantage in the competition over qualified co-workers.

A third body of studies show how legislation may have far-reaching consequences that may or may not be anticipated by legislators and policy-makers. Dobbin and Dowd (2000) and Dobbin (1994) discuss how antitrust laws influenced the development of the railway system in, for example, Massachusetts. The antitrust legislation altered the business model of key actors, and as actors demanded many investors to finance the costly development of the railway system, antitrust legislation created a finance market where railway companies could raise finance capital. 'Because firms bought the rivals at fair market prices, ownership was increasingly spread across many investors ... Under the finance model, then, more and more firms had large numbers of shareholders', Dobbin and Dowd (2000: 652) summarize. Dobbin's (1994) research monograph, on the other hand, stresses the connections, no matter how crooked or non-linear, between ideas 'about how economic rationality operates' and the legislation being put to place. Examining the differences between the American, the French and the British railroad systems development, Dobbin (1994) identifies three distinct and locally embedded economic policies regarding the railroad industry:

Because Americans believed that competition between localities would spur growth and that federal action would merely spawn graft, most American railroads backed state and local government financing but not federal financing. Because the French believed that growth must be orchestrated by the central state, French railroads backed central state financing but eschewed provincial and local financing as irrational. Because the British believed that 
all government meddling was inefficient, British railroads opposed government financing of all kinds. These and other ideas about self-interest were clearly conditioned by national context. (Dobbin, 1994: 214)

Depending on historical conditions, political conditions and the influence of certain groups, and other socio-economic and cultural conditions, these three leading industrial nations developed their own idiosyncratic railway industry policy, but somewhat surprisingly, while choosing different routes and bringing different equipment to move from $\mathrm{A}$ to $\mathrm{B}$, the three countries eventually arrived more or less at the same point, Dobbin (1994) says:

Many policy analysts begin with the assumption that transcendental economic laws govern the universe, and take policy to be responsive to those laws ... Two kinds of evidence undermine such economic determinism. First, I review evidence that policies organized around widely different economic principles produced similar outcomes in terms of industry growth and prosperity. Second, I review evidence that the economic laws these nations discovered reflect local institutional history rather than exogenous, transhistorical laws. (Dobbin, 1994: 222, emphasis added)

In the case of the railway system development as an industrial policy programme, the idea of the role of the state and private enterprising were mixed up with local conditions, and there were many cases of how existing legislation was used to motivate certain decisions. Dobbin (1994) thus concludes that antitrust legislation is more of a framework wherein the intentions regarding the favours of free competition expressed by the legislator can be temporarily compromised if there are other benefits emerging en route. Violating the law is thus tolerable at times, as long as it produces beneficial effects, if the violation is only temporal, and if no single actor can benefit handsomely from such violations. In other words, the coupling between legal texts and corporate and industrial practice is at times loose, providing executives and legal advisors with some degrees of freedom when interpreting a piece of new legislation.

At the end of the day, the role of law and regulation is widely underappreciated by the public, also including industry representatives, Dobbin and Dowd (2000: 653) propose: '[d]espite much evidence that antitrust law revolutionized America's industrial environment, it plays at best a supporting role in theories of industrial organization'. In the case of the US, a general sense of the government being all too prone to meddle with business matters and a general anti-statist sentiment in parts of American society further breed the idea that federal policy is inefficient and perhaps even illegitimate in terms of reducing market 
efficiency (Kelly and Dobbin, 1999: 457: Campbell and Lindberg, 1990: 642). In addition, organization theorists and management scholars have paid 'scant attention to the role of the state in shaping the behavior of organizations', Kelly and Dobbin (1999: 458) suggest. Against this relatively widespread ignorance regarding legislation and regulatory matters, the institutional theory view of law and the process of the managerialization of law present a more affirmative understanding of how legislation shapes and informs corporations.

\section{THE FIDUCIARY COMPONENT OF CORPORATE LAW}

Whenever there is a difference between 'laws in books' and 'laws in real life', there is a need for actors to interpret their practices and to conduct their decisions within the horizon of social interest and wider social objectives (Commons, 1924). 'The businessman should be actuated by the motive of serving society rather than maximizing profit as the sole end of enterprise', Howard Bowen (1953: 39) argued in his work Social Responsibilities of the Businessman. Bowen continues: '[t]he businessman should be imbued with respect for the dignity and essential worth of all men and with a spirit of compassion, shown in his relationship with his workers, customers, suppliers, competitors, and others with whom he has business dealings' (Bowen, 1953: 40).

This attitude towards the businessman has radically changed since the early 1950s, today being understood widely as serving a narrower set of stakeholders, but there are legal scholars who maintain that the work of corporate governance and leadership, despite the strong influence of shareholder welfare advocacy, should be understood as a fiduciary duty. Stout (2004) suggests that both executives and directors are given fiduciary duties in managing the corporation so that it benefits society in a broad sense of the term. Rent-seeking and self-serving homo economicus-type individuals are thus not attractive to recruit to such positions. Also practising managers such as Sherron Watkins (2003), serving as an executive and whistleblower during the Enron bankruptcy, one of the most emblematic corporate collapses in the post-World War II period (see, for example, Tourish and Vatcha, 2005; Craig and Amernic, 2004; Seeger and Ulmer, 2003), stress the need for emphasizing the fiduciary duties of executives and managers: '[i]n order to flourish, a successful capitalist system must be predicated on fairness, honesty, and integrity. In fact, many scholars describe the capitalist system as a three-legged stool - economic freedom, political freedom, and moral responsibility. A weakness of one and the stool topples' (Watkins, 2003: 122). ${ }^{2}$ 
Several empirical studies reveal how, for example, 'narcissistic leaders', triggered by the scenario of creating extra-normal profits but indifferent to downside risks, ignore their fiduciary responsibilities and therefore put the corporation's assets at stake (for example, Chatterjee and Hambrick, 2007), thus violating the intentions of the legislators. Such leaders increase levels of risk while producing little additional rent on the basis of this risk exposure: 'although narcissists tend to generate more extreme and irregular performance than non-narcissists, they do not generate systematically better or worse performance' (Chatterjee and Hambrick, 2007: 378). From a mainstream rational choice theory view, the failure to adhere to the fiduciary duties makes these executives unattractive for corporations.

Almandoz (2014) studied the role of founding teams in banks and speaks favourably of what he calls a 'community logic', a term that can be accommodated within the fiduciary duty view of leadership and corporate governance work. The board of directors in banks operating in accordance with a 'financial logic' rather than a 'community logic' were more prone to making use of 'risky deposits', Almandoz (2014: 458) found. In addition, boards containing a larger share of directors with a 'finance career background' increased the risk-taking (Almandoz, 2014: 459). This finding, emphasizing the local community as a beneficiary of qualified and professional leadership work, is consistent with, for example, Kerr and Robinson's (2011: 152) study of Scottish bankers, failing to connect to both the local market and their organizations (that is, their fiduciary duties were more or less abandoned altogether), ultimately leading to the bankers 'destroying the businesses that they were charged with managing'.

\section{SUMMARY AND CONCLUSION}

All economic enterprising and business venturing is, more or less explicitly, based on self-interest and some consuming of energy and efforts on part of the founders, entrepreneurs and promoters of a new business. In addition, in a differentiated economy, economic activities include diverse skills and sources of expertise and therefore demand coordination and agreements between participating business partners. Based on these premises, policy-makers and regulators representing the sovereign state face the thorny question of how to protect the business from opportunistic behaviour and fraud, deriving both from outside as well as inside the firm. One solution to this governance problem is to enact legal statutes that specify the roles and rights of the business 
promoters but also the role of investors who supply the finance capital. A business charter is thus the incorporation of a new firm under the regime of pre-existing state-based or federal legal frameworks. As the legal statutes cannot be too detailed or too complicated to understand - which would undermine the possibilities for law enforcement and court ruling, or make the business partners' and financiers' contract inoperable corporate law is primarily specifying a general set of rules. At the same time, these rules include quite complex terms such as fiduciary duties, stressing that 'laws in books' and 'laws in real life' in many cases diverge. This leaves room both for interpretation of the intentions of the legislators, but also, critics contend, opens up for what is called moral hazard, the risk that participants act in self-interested ways without the risk of being punished for this undesirable behaviour. Ultimately, despite these concerns, corporate law, granting the directors a central role in the firm's corporate governance structure, remains the best protection for the greater number of participants, legalists argue. As will be debated in the succeeding chapters, a contractarian view of the firm advocates 'the market for corporate control' as a more efficient mechanism than legislation and court ruling for reducing the risks of moral hazard and forms of self-serving behaviour, most notably managerial malfeasance. In the contractarian view, the legislative model of corporate governance marginalizes market information and makes legislators - in the case of disputes - the privileged interpreters of such market information. In other words, the discourse on corporate governance is based on the tension between the concept of trust and the concept of contract, representing two, if not competing, at least complementary governance models.

\section{NOTES}

1. Djelic (2013) shows that the development of limited liability as a legal concept was a long and complicated political process. Following a major economic and financial crisis in the United Kingdom, the so-called Bubble Act 1720 reaffirmed that joint stock companies '[c]ould only exist if they were chartered by royal or parliamentary fiat', and this legislation '[s]ignificantly slowed down the progress of legal incorporation in Britain for the rest of the century' (Djelic, 2013: 601). However, as early as 1782, when the corporate form became increasingly popular in the United Kingdom, the independent Irish Parliament enacted the Partnership Act, the first attempt to institute limited liability as a legal statute. The Act had a limited impact on the Irish economy and was ultimately a failure as it did not increase the supply of finance capital in Ireland or otherwise boost the economy. In the mid-nineteenth century, limited liability was still 'a rare and dubious privilege' in the United Kingdom but the Incorporation Act of 1844 and the Limited Liability Act of 1855 served to make limited liability a 'natural attribute' of a corporate charter (Djelic, 2013: 599). These two Acts were 'undeniably liberal victories' (Djelic, 2013: 603) as they encouraged and legitimized the liberalization of the economy and the freedom of investment. In the period, the debate regarding the benefits and risks with limited liability 'was reaching its climax' (French, 
1990: 15; Bryer, 1997). Conservatives argued that limited liability was morally wrong inasmuch as it involved 'dishonouring obligations freely undertaken' (French, 1990: 15). Conservatives also worried about the fast pace of the British industrialization and argued that there was no shortage of finance capital in the British economy and that limited liability business charters would easily unleash a wave of dangerous speculation (Djelic, 2013: 610): '[t]he major argument against the introduction of general limited liability into mid-19th century Britain was that there was no need for it, as the rapidly expanding economy was generating a massive surplus of savings which eagerly sought out any investment opportunity', French (1990: 27) writes. That is, conservative commentators referred to what eventually would be discussed as moral hazard (Djelic and Bothello, 2013). Others, including John Stuart Mill, for example, proposed that limited liability would '[a]llow capital and profit-sharing schemes where workers and employees had a stake in common' (Djelic, 2013: 603), and more radical debaters and social reformers - including the so-called Chartist social movement and Christian socialists being active in the 1830 s and 1840 s claimed that limited liabilities would work in the best interests of labourers or society at large. Taken together, all these activities taking place between around 1720 and 1855 and well beyond the mid-nineteenth century tend to be overlooked and forgotten as we today '[t]end to take for granted both limited liability and its association with the corporate form' (Djelic, 2013: 596).

2. Watkins does not hesitate to speak up regarding her view of the Enron executives and the CEO Jeffrey Skilling in particular, calling for new legal practices to be able to prescribe sanctions against conspicuous opportunistic behaviour:

Jeffrey Skilling [...] resigned on August 14th [2001], citing personal reasons that never quite materialized [...] he had about $\$ 100$ million in the bank and so he basically decided to 'call in rich'. That, to me, is pathetic. I thought there should be the equivalent of a corporate court martial. A Navy battleship captain can't decide in the middle of a skirmish 'I'm tired and I'm going back to land'. He would be court martialed; you can't abandon your crew. (Watkins, 2003: 121)

'Skilling knew that we had hit an iceberg, that we were taking on water, that it was probably lethal, and he was choosing to go home', Watkins (2003: 121) adds, leaving little room for interpretation. Watkins' and other commentators' assessment of the Enron leadership strongly contrast with some pre-bankruptcy accounts, including, for example, Gary Hamel's management guru-style volume Leading the Revolution (2000), peppered with enthusiasm over Enron's ability to transform the energy market from being 'stodgy old-boys' clubs' into 'flexible energy markets that meet the everchanging needs of energy-hungry customers' (Hamel, 2000: 211). Hamel (2000: 219) speaks about the 'spectacular success' of Enron, and even explicitly addresses Enron's advanced 'risk management practices' as being one of their core competencies, two statements that were shattered to pieces (and possibly did not exactly boost the credibility of Hamel's academic and consultancy work) once the post-bankruptcy investigations revealed systematic fraud throughout the one-time seventh largest corporation in the US. To further underline how conspicuously the Enron executives and directors ignored their fiduciary duties and other professional norms and standards of decency, Watkins' article can be cited at length:

[On 3 December 2001] the employees were told to get back to their desks, pack up personal items, and leave [... In contrast] 25 executives received three-months retention bonuses in the last week of November 2001 [...] These 25 executives paid themselves nearly $\$ 55$ million. One person got $\$ 8$ million, another $\$ 5$ million, another $\$ 2$ million, two more paid themselves $\$ 1.5$ million, several people received $\$ 700,000, \$ 600,000$, and $\$ 400,000$ bonuses. Enron's annual salaries for these managing directors were closer to $\$ 300,000$ per year - so many of these 'special' bonuses were three to five times annual base pay. (Watkins, 2003: 122)

No wonder the term 'Enronitis', meaning 'a situation in which large corporations fail to secure investment because they are suspected of fraud and mismanagement' (Collins 
English Dictionary, accessed 27 May 2015 at: http://www.collinsdictionary.com/dictionary/ english/enronitis), is the lasting heritage of Enron. Another consequence is the SarbanesOxley Act. 